\title{
MODELE BIZNESU A CYKL ŻYCIA STARTUPÓW INTERNETOWYCH - STUDIUM PRZYPADKU
}

DOI: $10.33141 /$ po.2019.09.06

\author{
Hanna Nowak, Krzysztof Łuczak
}

\section{Wprowadzenie}

W ykorzystanie sieci internetowej oraz bazujących na niej urządzeń doprowadziło do reorganizacji działalności przedsiębiorstw. Zastosowanie technologii ICT wiązało się przede wszystkim $\mathrm{z}$ usprawnianiem procesów zachodzących w organizacjach, łatwiejszą komunikacją oraz szybszym dostępem do informacji. Z czasem zauważono możliwości wprowadzania zmian i innowacji w dotychczasowych modelach biznesu (Amit, Zott, 2001; Falencikowski, 2013, s. 16-17). Na początku odkrywane przez nowych przedsiębiorców okazje rynkowe były związane w dużej mierze z przenoszeniem fizycznych procesów do środowiska wirtualnego (Szpringer, 2012, s. 44; Blank, Dorf, 2013, s. 32). W oparciu o wykorzystanie Internetu i technologii mobilnych możliwe stało się też tworzenie nowych rynków, produktów i usług, a w związku z tym także nowych modeli e-biznesu (Szpringer, 2012, s. 9-11).

Interesującym $\mathrm{z}$ punktu widzenia badawczego zagadnieniem wydaje się przełożenie uwarunkowań związanych $\mathrm{z}$ postępem technologicznym i rozwojem rynku e-commerce oraz m-commerce na cykl życia tzw. startupów internetowych, które ze względu na swoją specyfikę różnią się od większości przedsiębiorstw postrzeganych jako „typowe”, funkcjonujących w gospodarkach poszczególnych krajów. Wyróżnienie tej grupy przedsiębiorstw w ramach sektora MŚP jest istotne nie tylko z punktu widzenia ich wpływu na wzrost innowacyjności gospodarki czy globalny zasięg powiązań (Startup Poland, 2016, s. 6-7), ale również $\mathrm{z}$ powodu spodziewanych różnic $\mathrm{w}$ przebiegu poszczególnych faz ich rozwoju.

Etapowość rozwoju przedsiębiorstw jest przedmiotem wielu opracowań naukowych, przy czym zwraca się uwagę zarówno na aspekt ilościowy, jak i jakościowy przemian związanych $\mathrm{z}$ poszczególnymi fazami cyklu życia (Wasilczuk, 2004; Matejun, 2016). W odniesieniu do sektora MŚP podkreśla się także różnice w etapach rozwoju z uwzględnieniem faz statycznych (np. faza przedzałożycielska) i dynamicznych (np. faza ekspansji), które charakteryzują się odmiennym natężeniem aktywności inwestycyjnej i rynkowej (Matejun, 2016, s. 96-98).

W kontekście poszukiwania służących rozwojowi przedsiębiorstwa przewag konkurencyjnych, w szczególności w ujęciu sektorowym, w literaturze zwraca się uwagę na modele biznesu jako narzędzia reorientacji strategicznej przedsiębiorstw (Nogalski, 2009). Wraz ze zmianami modeli biznesowych polegającymi na wdrażaniu innowacji zaobserwowano poprawę w zakresie oferty produktowej, zarówno w wymiarze jakościowym, jak i ilościowym oraz powiązany z nią wzrost sprzedaży (Brzóska, Jelonek, 2015). Modele biznesu i ich zmiany (innowacje modelu biznesu) są postrzegane jako czynnik wywierający wpływ na przetrwanie i rozwój firmy, w szczególności w odniesieniu do rozwiązań bazujących na ICT (Doligalski, 2014, s. 26).

Celem artykułu jest identyfikacja faz cyklu życia startupu internetowego bazującego na aplikacji mobilnej w odniesieniu do typowych ścieżek rozwoju organizacji. Przesłanki dotyczące specyfiki startupów w tym zakresie wynikają zarówno ze studiów literaturowych dotyczących modeli e-biznesu, jak i z obserwacji konkretnych przykładów rozwoju tego typu organizacji w praktyce gospodarczej. W kontekście dynamicznych zmian w otoczeniu technologicznym reorganizacja modelu biznesu w kierunku rozwiązań internetowych i mobilnych jest postrzegana jako czynnik sprzyjający szybszemu reagowaniu na zmiany i odkrywaniu okazji rynkowych, co ułatwia osiągnięcie przewagi konkurencyjnej oraz sukcesu przedsiębiorstwa. Znajduje to swoje odzwierciedlenie w zmianach konfiguracji zmiennych o charakterze jakościowym i ilościowym, które definiują poszczególne etapy cyklu życia organizacji.

Zmiany dynamiki rozwoju poszczególnych grup podmiotów gospodarczych (np. przyspieszenie, skrócenie faz cyklu życia, dynamiczny wzrost) są składową przemian sytuacji gospodarczej kraju czy regionu. Stąd wiedza na 
temat czynników wywierających wpływ na cykl życia startupów internetowych może być przydatna nie tylko z perspektywy mikro-, ale również makroekonomicznej.

\section{Metoda badawcza}

W artykule dokonano przeglądu literatury z zakresu modeli biznesu organizacji typu startup działających $\mathrm{w}$ ramach rynków e-commerce oraz $m$-commerce, a także z zakresu modeli cyklu życia organizacji. W części empirycznej wykorzystano metodę studium przypadku, odnosząc się do startupu zaliczanego do grupy przedsiębiorstw bazujących na technologiach mobilnych - Qpony. pl Sp. z o.o., którego model biznesu został bardziej szczegółowo opisany w dalszej części artykułu.

W celu pozyskania danych empirycznych wykorzystano różne źródła i techniki badawcze. W styczniu 2016 roku przeprowadzono wywiad pogłębiony $\mathrm{z}$ jednym z twórców startupu, który do maja 2017 roku pozostawał operacyjnie zaangażowany w rozwój organizacji. Następnie, współtwórca startupu jako współautor niniejszego artykułu dokonał identyfikacji kluczowych decyzji w ramach zarządzania przedsiębiorczego, które wiązały się z osiąganiem kolejnych etapów cyklu życia organizacji przy uwzględnieniu opisanego w kolejnej części artykułu modelu Canvas (Osterwalder, Pinguer, 2010). W celu zminimalizowania zagrożenia nadmiernym subiektywizmem $\mathrm{w}$ interpretacji zdarzeń otrzymane w ten sposób informacje zestawiono ze źródłami prasowymi i branżowymi dotyczącymi rozwoju analizowanego startupu oraz danymi liczbowymi wynikającymi ze sprawozdań finansowych jednostki, dostępnymi w internetowym serwisie Krajowego Rejestru Sądowego (eKRS). Studium przypadku uwzględnia więc zarówno charakterystykę zmian jakościowych w funkcjonowaniu startupu, jak i parametry ilościowe, takie jak przychody ze sprzedaży, koszty oraz zysk/stratę ze sprzedaży w latach 2012-2017.

Podmiot badania należy do społeczności około 2,8 tysięcy startupów działających w Polsce, które zostały scharakteryzowane w raporcie pt. „Polskie Startupy 2017” (Startup Poland, 2017). Z uwagi na to, że startupy są przedsięwzięciami obarczonymi dużym ryzykiem i większość z nich upada (Startup Poland, 2017, s. 9), Qpony.pl Sp. z o.o. należy uznać za przykład sukcesu rynkowego, gdyż rok 2017 spółka ta zakończyła wzrostem przychodu rok do roku wynoszącym ponad 100\% i zyskiem ze sprzedaży w wysokości 914,2 tys. zł (Krajowy Rejestr Sądowy, 2019). Ponadto jako podmiot reprezentujący przedsiębiorstwa zaliczane do sektora gospodarki cyfrowej posiada jednocześnie stosunkowo długi staż funkcjonowania na rynku w porównaniu do innych startupów, co pozwala na identyfikację i analizę faz jego rozwoju w kontekście zmian przyjętego modelu biznesu.

\section{Pojęcie i modele biznesu startupów internetowych}

$\mathrm{S}$ tartup jest pojęciem wykorzystywanym w badaniach naukowych i analizach gospodarczych w sposób niejednoznaczny. Choć nie dotyczy wyłącznie organizacji, których modele biznesu bazują na zastosowaniu Internetu, w dużej mierze organizacje tego typu są kojarzone $\mathrm{z}$ rozwojem rynku cyfrowego. Przykładowo, na potrzeby badań przeprowadzanych przez Startup Poland, startup jest definiowany jako „przedsięwzięcie, które spełnia przynajmniej jeden $\mathrm{z}$ dwóch warunków: należy do sektora gospodarki cyfrowej (...) lub tworzy nowe rozwiązania technologiczne w obszarze IT/ICT" (Startup Poland, 2016, s. 12). Wzrost zainteresowania modelami biznesu ze strony naukowców w latach 90. XX wieku również był związany z nowymi możliwościami działalności przedsiębiorstw w przestrzeni wirtualnej (Falencikowski, 2013, s. 16-17). Z kolei definicja zaproponowana przez S. Blanka i B. Dorfa (2013, s. 19), określająca startup jako „tymczasową organizację zajmującą się poszukiwaniem skalowalnego, powtarzalnego i rentownego modelu biznesowego", nie ogranicza tego pojęcia wyłącznie do tzw. startupów technologicznych, do których można zaliczyć startupy internetowe i mobilne. Autorzy wprowadzają wyraźne kryterium różnicujące startupy $\mathrm{z}$ uwagi na fizyczne produkty i kanały dystrybucji oraz produkty i kanały internetowe lub mobilne (Blank, Dorf, 2013, s. 8).

Biorąc pod uwage powyższe rozważania, w artykule posłużono się pojęciem startupu internetowego bazującego na aplikacji mobilnej, który jest rozumiany jako organizacja typu startup, należąca do kategorii startupów technologicznych (w tym przypadku wykorzystujących technologie informacyjno-komunikacyjne), oferująca produkty i usługi internetowe oraz wykorzystująca kanał mobilny (aplikacja mobilna dostępna na smartfony).

W literaturze zwraca się uwagę na fakt, że startup nie jest „mniejszą wersją dużej firmy” (Blank, Dorf, 2013, s. 16), ale pewnym szczególnym rodzajem organizacji, która powinna być traktowana w odmienny sposób i przy innych metodach zarządzania (Glinka, Pasieczny, 2015, s. 18). Jedną z metod stosowanych przez twórców startupów internetowych i mobilnych jest projektowanie modeli biznesu przy wykorzystaniu praktycznego narzędzia, jakim jest 9-elementowy szablon (canvas) przedstawiony przez A. Osterwaldera i Y. Pigneura (2010). Szablon ten odzwierciedla podstawowe elementy koncepcji działalności przedsiębiorstwa w następujących obszarach: propozycja wartości, segmenty klientów, kanały dystrybucji, relacje z klientami, strumienie przychodów, zasoby, działania, partnerzy i struktura kosztów (Blank, Dorf, 2013, s. 78). Model biznesowy jest więc sposobem przeniesienia odkrytych możliwości czy okazji biznesowych na konkretny i spójny projekt, który uwzględnia najważniejsze elementy funkcjonowania organizacji w otoczeniu, w tym przede wszystkim sposób tworzenia wartości dla klienta (Glinka, Pasieczny, 2015, s. 83). Proces tworzenia modelu biznesowego ma jednak charakter dynamiczny - poszczególne elementy modelu są testowane $\mathrm{w}$ fazie tworzenia startupu przy wykorzystaniu podejścia Customer Development w celu dopracowania modelu (Blank, Dorf, 2013, s. 8; Glinka, Pasieczny, 2015, s. 100).

Wśród modeli e-biznesu bazujących na wykorzystaniu Internetu można wyróżnić (Szpringer, 2012, s. 43): modele przeniesione ze świata realnego oraz modele innowacyjne 
- opisujące rodzaje działalności, które nie istniały, zanim pojawił się Internet. Podobne kryterium podziału można zastosować do modeli biznesu bazujących na aplikacjach mobilnych. Nowe uwarunkowania technologiczne funkcjonowania tej grupy przedsiębiorstw rodzą pytania o przebieg ich rozwoju w kontekście modeli cyklu życia organizacji.

\section{Cykl życia organizacji - typowa czy zindywidualizowana ścieżka rozwoju?}

$\mathbf{C}_{2}$ ykl życia organizacji jest procesem, którym można zarządzać (Adizes, 2015), w trakcie którego organizacja przechodzi przez różne etapy w dążeniu do szeroko rozumianego rozwoju. Rozwój może być rozumiany jako proces przekształceń prowadzących do osiągania bardziej złożonych lub doskonalszych stanów lub form (Szpringer, 2012, s. 15). W każdym $z$ etapów rozwoju organizacja charakteryzuje się określonym środowiskiem wewnętrznym i potrzebami, a jej funkcjonowanie jest determinowane również interakcjami ze środowiskiem zewnętrznym (Kurowska i in., 2013, s. 25; Glinka, Pasieczny, 2015, s. 245) wpływającym na decyzje podejmowane przez osobę lub osoby zarządzające organizacją. Ujęcia modelowe pomagają zobrazować przebieg cyklu życia organizacji, jednak w praktyce rozwój każdego podmiotu zależy od szeregu czynników, w tym między innymi od podejścia osoby zarządzającej, której decyzje (np. wybór modelu biznesu) wpływają na cykl życia danego przedsiębiorstwa.

$\mathrm{Z}$ uwagi na stosunkowo nowe zjawisko tworzenia modeli biznesu startupów internetowych i mobilnych przebieg ich rozwoju w kontekście tradycyjnych modeli cyklu życia organizacji oraz identyfikacja ewentualnych różnic i podobieństw wymagają podjęcia dalszych szczegółowych badań. Zadanie to jest utrudnione ze względu na fakt, że wiele nowych startupów nie osiąga dojrzałości i ma problemy z przetrwaniem początkowych etapów cyklu życia.

W tradycyjnych ujęciach modeli cyklu życia organizacji wyróżnia się zazwyczaj kilka etapów, najczęściej od 2 do 5 (Świeszczak, 2016, s. 39), przy czym do często przywoływanych w literaturze koncepcji zalicza się model L. Greinera (1998), a także koncepcję N.C. Churchilla oraz V.L. Lewis (1983). Na uwagę zasługuje również ogólna teoria faz rozwoju S. Spinelliego i R. Adamsa, przywołana przez B. Glinkę i J. Pasiecznego (2015, s. 242).

$\mathrm{Z}$ punktu widzenia analizy cyklu życia organizacji istotne znaczenie ma to, jakimi ścieżkami rozwoju podążają nowo tworzone organizacje. Z jednej strony podkreśla się $\mathrm{w}$ literaturze istnienie typowej, czyli pewnej powtarzalnej ścieżki, którą przetestowały już inne przedsiębiorstwa (Blank, Dorf, 2013, s. 26). Z drugiej natomiast strony zwraca się uwagę na fakt, że każde przedsiębiorstwo napotyka na swojej drodze różne wyzwania i w przypadku każdej organizacji cykl rozwoju jest zindywidualizowany, między innymi w zakresie tempa rozwoju, co może prowadzić także do uzyskania odmiennych rezultatów działalności (Glinka, Pasieczny, 2015, s. 245). Także modele biznesu różnych przedsiębiorstw mogą się od siebie różnić nawet w ramach tej samej branży (Falencikowski, 2013, s. 6).
W związku z powyższym twórcy nowych przedsiębiorstw reprezentują różne podejścia do ich rozwoju i wzrostu. Wśród nich można wymienić (Glinka, Pasieczny, 2015, s. 240): rozwój utożsamiany ze wzrostem (np. wzrost liczby klientów, pracowników, wzrost wartości transakcji); rozwój utożsamiany z poprawą jakości $\mathrm{w}$ funkcjonowaniu przedsiębiorstwa (np. udoskonalenie produktów); sprzedaż utworzonego przedsiębiorstwa lub zapewnienie przetrwania i utrzymanie działalności na określonym poziomie. Odmienne podejścia w tym zakresie wyraźne są pomiędzy większością przedsiębiorstw sektora MŚP a startupami bazującymi na modelach e-biznesu. Różnice w działalności startupów internetowych i mobilnych w porównaniu do przedsiębiorstw wykorzystujących tradycyjne, fizyczne kanały dystrybucji przejawiają się bowiem między innymi w przyspieszeniu procesów związanych $\mathrm{z}$ tworzeniem i ulepszaniem produktu oraz tworzeniem wartości dla klienta. Zdecydowanemu skróceniu ulega również sam proces tworzenia startupu (Blank, Dorf, 2013, s. 6, 30-32).

Według różnych źródeł, poszczególne fazy rozwoju przedsiębiorstw przyjmują odmienne nazwy, a w wielu ujęciach startup jest traktowany jako jeden $\mathrm{z}$ etapów procesu założycielskiego. W tabeli 1 zestawiono wybrane określenia charakteryzujące tworzenie i rozwój przedsiębiorstwa w ujęciu ogólnym z podejściem koncentrującym się na rozwoju startupu jako organizacji. W przypadku startupów technologicznych, w tym internetowych, ustalenie fazy cyklu życia może odbywać się na podstawie analizy dwóch zmiennych: sposobu i wysokości finansowania oraz zyskowności realizowanego projektu (Giełzak, Krok, 2016). Zasadniczą cechą startupów jest brak stabilnego modelu biznesowego, efektem czego jest ujemna rentowność $\mathrm{w}$ pierwszych latach działalności. Identyfikacja fazy cyklu życia ma istotne znaczenie w kontekście wyceny przedsiębiorstwa, jak również dla celów zarządczych zarówno z perspektywy kadry zarządzającej, jak i inwestorów.

\section{Studium przypadku startupu internetowego bazującego na technologiach mobilnych - Qpony.pl Sp. z o.o.}

$\mathbf{P}$ rzedmiotem działalności startupu Qpony.pl Sp. z o.o. są technologie mobilne, a w szczególności aplikacje mobilne. Zgodnie z klasyfikacją przedstawioną przez M. Kardasa (2016), badany podmiot funkcjonuje według modelu ukrytych przychodów (hidden revenues) i cyfryzacji. Oznacza to, że oferuje swoje produkty i usługi w formie cyfrowej, dzięki czemu możliwa jest łatwiejsza i szybsza dystrybucja. W modelu ukrytych przychodów produkty i usługi dostępne są nieodpłatnie, a użytkownicy nie są głównym źródłem przychodów. Przychody generują inne podmioty, np. reklamodawcy (Kardas, 2016, s. 315).

W 2018 roku przedsiębiorstwo było właścicielem trzech aplikacji mobilnych ułatwiających konsumentom codzienne zakupy. Były to aplikacje Qpony, Blix oraz Zdrowe Zakupy, a każda $\mathrm{z}$ nich posiadała ponad milion 


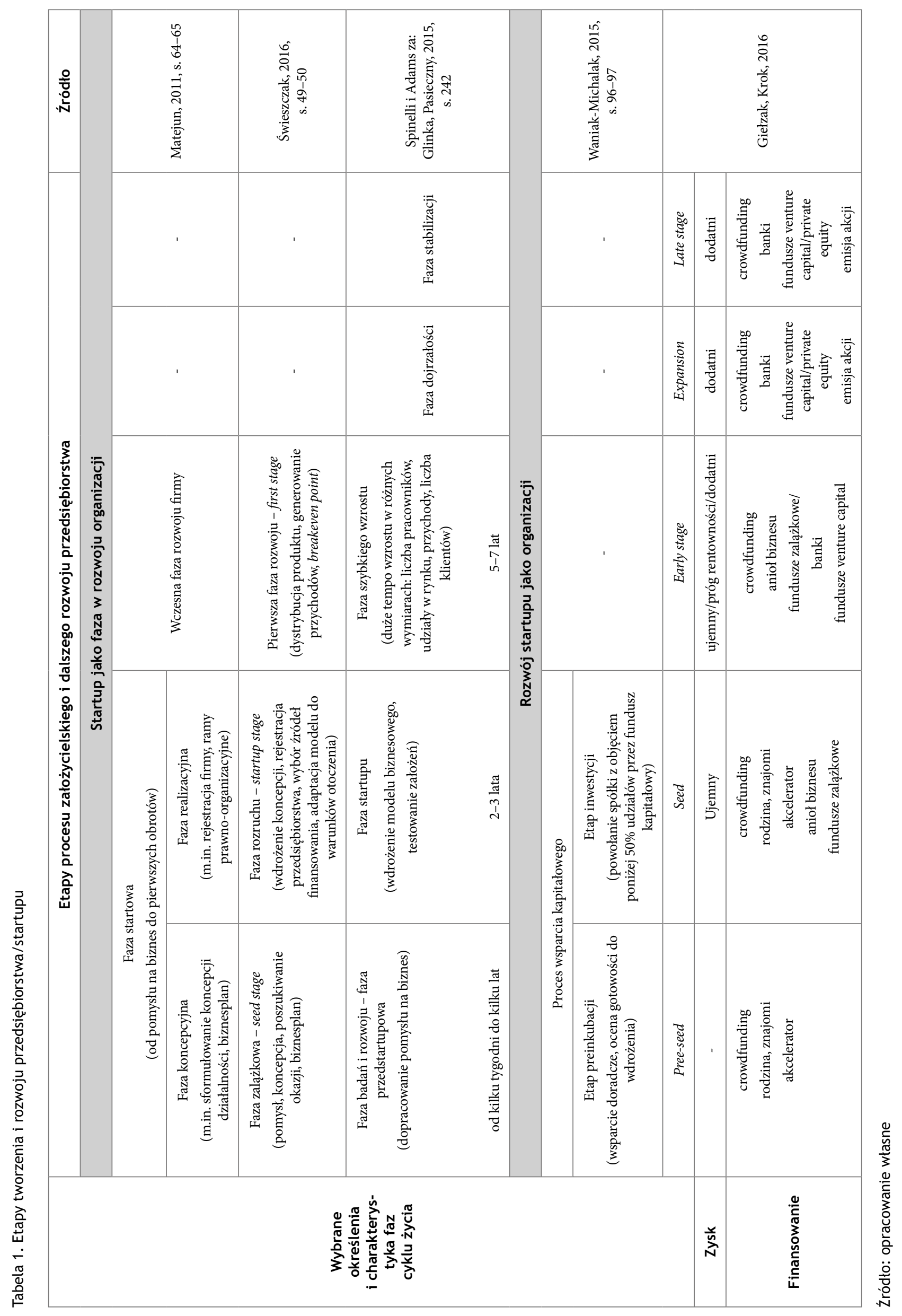


instalacji (Google Play, 2018). Aplikacje te pomagają konsumentom zapoznać się z ofertą sieci handlowych, dowiadywać się o promocjach, tworzyć listy zakupowe, a także sprawdzać składy produktów spożywczych.

Startup rozpoczął swoją działalność w Poznaniu w Akademickich Inkubatorach Przedsiębiorczości mieszczących się na Uniwersytecie Ekonomicznym w Poznaniu. Założycielami były trzy osoby, które kolejno dołączały do zespołu. Inspiracją do rozpoczęcia działalności była analiza popularnego modelu kuponów rabatowych szeroko wykorzystywanego w Stanach Zjednoczonych, z którego według różnych źródeł korzysta ponad 80\% Amerykanów (Carter, 2017). Rynek kuponów rabatowych, zapoczątkowany w 1887 roku przez firmę Coca-Cola poprzez rozdawanie z butelką napoju kuponu na odbiór darmowej szklanki (Tuttle, 2010), wart jest dzisiaj dziesiątki miliardów dolarów. Korzystając z doświadczeń rynku amerykańskiego, podjęto próbę implementacji podobnego modelu biznesowego w Polsce.

Analizowany startup rozpoczął fazę pre-seed w 2010 roku w Akademickich Inkubatorach Przedsiębiorczości, organizacji non-profit działającej przy uczelniach i pomagającej młodym przedsiębiorcom $\mathrm{w}$ przygotowaniu pomysłu biznesowego do wejścia na rynek. Faza pre-seed nazywana jest również fazą preinkubacji, a startup na tym etapie pracuje nad modelem biznesowym, osiągając jedynie niewielkie przychody bądź nieposiadając ich w ogóle. $\mathrm{W}$ początkowym etapie analizowany startup, korzystając $\mathrm{z}$ osobowości prawnej fundacji AIP, rozwijał produkt w postaci papierowego katalogu rabatowego do walidacji modelu biznesowego opartego o kupony rabatowe. Kluczowym segmentem klientów na początkowym etapie byli lokalni przedsiębiorcy oraz sieci restauracji.

Dynamiczny rozwój smartfonizacji oraz aplikacji mobilnych, który nastąpił po premierze pierwszego telefonu komórkowego, którego można nazwać smartfonem (Ritchie, 2017), sprawił, że pojawiła się okazja do zaistnienia w nowym kanale komunikacji z klientem. W Polsce dynamiczny wzrost wykorzystania smartfonów nastąpił po 2010 roku. W 2012 roku około 25\% Polaków posiadało smartfona (Galica, 2012 za: Kopecka-Piech, 2013, s. 11). Otworzyło to możliwość przeniesienia modelu biznesowego startupu do postaci elektronicznej, z użyciem telefonu komórkowego i Internetu w celu łączenia sprzedających z kupującymi, wykorzystując do tego szeroko rozumianą ideę kuponów rabatowych. W odróżnieniu od tradycyjnego biznesu, który bazuje na stałych i dobrze znanych fizycznych kanałach dystrybucji, analizowany podmiot zdecydował się na zmianę kanału dystrybucji, co zaskutkowało reorientacją modelu biznesowego. W drugim kwartale 2011 roku rozpoczęły się prace nad aplikacją mobilną, która miała swoją premierę w maju 2012 roku.

W czerwcu 2012 roku startup pozyskał finansowanie kapitałowe i przekształcił się w spółkę z ograniczoną odpowiedzialnością (Newsweek, 2012). Od tego momentu kluczowym aspektem stał się rozwój kanału mobilnego rozumianego jako aplikacja mobilna dostępna na smartfony. Charakterystyką produktów internetowych jest szybsze przechodzenie przez fazy rozwoju oraz opieranie modelu biznesowego o aktywa niematerialne, jakimi są użytkownicy. To użytkownicy i ich zachowania w stosunku do produktu determinują możliwość rozwoju i monetyzacji produktów internetowych. Unikalną cechą produktów internetowych jest możliwość walidacji sprzedaży i powodzenia produktu podczas początkowych etapów rozwoju. Dzieje się tak, ponieważ Internet eliminuje bariery ograniczające możliwość dotarcia niematerialnego produktu do konsumentów (Porter, 2006, s. 19).

Reorientacja kanału sprzedaży $\mathrm{z}$ tradycyjnego w kierunku cyfrowego wpłynęła na zmianę postrzegania kluczowych zasobów warunkujących kształtowanie się przewagi konkurencyjnej. W branży aplikacji mobilnych kluczowy zasób stanowi posiadanie aktywnej instalacji oprogramowania na smartfonie klienta. Tylko wówczas możliwe jest wykorzystanie telefonu w celu komunikacji i dostarczania treści. Miesięczna liczba aktywnych użytkowników aplikacji (ang. MAU - Monthly Active Users) przyjmowana jest często jako miernik potencjału w kanale mobilnym. Liczba użytkowników aplikacji stanowi miarę wartości startupów technologicznych, która w lepszym stopniu niż poziom przychodów odnosi się do celu współczesnego zarządzania opartego na paradygmacie maksymalizacji wartości przedsiębiorstwa (Dobiegała-Korona, 2012).

W 2014 roku spółka pozyskała nowego inwestora, który wykupił udziały poprzedniego funduszu seed za kwotę $1 \mathrm{mln}$ zł i zainwestował w spółkę nowe środki (Inkubatory.pl, 2015). Moment ten można uznać za przejście z fazy zalążkowej do fazy wczesnego wzrostu. Faza zalążkowa trwała dwa lata i jest to czas niewiele odbiegający od standardów amerykańskich, zgodnie z którymi przyjmuje się, że faza seed trwa od 12 do 18 miesięcy (Basich, 2014, s. 3).

W Stanach Zjednoczonych przyjmuje się, że przeciętna inwestycja na poziomie seed mieści się $\mathrm{w}$ przedziale od 500 tys. do 1 mln dolarów, a pozyskany w ten sposób kapitał startup powinien przeznaczyć na rozwój produktu do postaci minimalnego gotowego produktu do wprowadzenia na rynek (ang. MVP - Minimum Viable Product). Faza wczesnego wzrostu (early stage lub $A$ round), która trwała w analizowanym przypadku od 2014 do roku 2016 uznawana jest za okres, w którym startup poszukuje optymalnego modelu biznesowego, który jest w stanie zaspokoić oczekiwania zarówno założycieli, jak i inwestorów (Damodaran, 2009 s. 3-16). Według A. Damodarana (2009 s. 15), na tym etapie inwestorzy oczekują zwrotów $\mathrm{z}$ inwestycji na poziomie $40-60 \%$.

Analizowana spółka w ciągu dwóch lat osiągnęła pozycję jednej z najczęściej pobieranych aplikacji kuponowych w Polsce. W 2016 roku spółka dokonała przejęcia mobilnego agregatora gazetek reklamowych (Mamstartup. pl, 2016). Dzięki aplikacji podobnego obszaru spółka powiększyła swoje udziały w rynku mobilnych agregatorów promocji, uzyskując pozycję jednego $\mathrm{z}$ największych podmiotów w segmencie m-commerce w Polsce. Decyzja o rozwoju kanału mobilnego była jednym z kluczowych czynników sukcesu analizowanej organizacji, gdyż 
umożliwiła uzyskanie w ciągu czterech lat ponad miliona użytkowników (Dziennik Internautów, 2016). Również w 2016 roku spółka dokonała pierwszej ekspansji zagranicznej. Te dwa zdarzenia, a mianowicie akwizycja oraz ekspansja zagraniczna, świadczą o przejściu startupu do fazy wzrostu i ekspansji. Podsumowanie poszczególnych faz rozwoju zostało zaprezentowane w tabeli 2 .

\section{Wnioski}

$\mathbf{P}$ rzedstawiony w artykule przykład ukazuje przebieg rozwoju organizacji typu startup, która wypracowuje model biznesu w oparciu o technologie mobilne. Na podstawie przedstawionych $\mathrm{w}$ tabeli 3 danych można stwierdzić, że osiągnięcie dodatniego wyniku finan- sowego (zysku ze sprzedaży) nie było podstawowym warunkiem funkcjonowania badanego startupu w początkowych fazach jego cyklu życia. Pomimo tego, iż próg rentowności został osiągnięty stosunkowo późno, kierując się kryterium czasu (rok 2017), to jednak wysoka dynamika zmian zarówno przychodów, jak i kosztów w początkowych fazach funkcjonowania spółki (w fazie zalążkowej oraz wczesnego wzrostu) świadczy o dużej aktywności rynkowej i inwestycyjnej tego podmiotu. Jest to związane z podejściem właścicieli tego typu organizacji do kształtowania ich cyklu życia. Podstawowym wyznacznikiem startupów technologicznych jest liczba użytkowników i klientów danego rozwiązania technologicznego, ich poziom zaangażowania i aktywności. $\mathrm{W}$ trakcie dynamicznego wzrostu startupu nie bierze się

Tabela 2. Fazy rozwoju organizacji - startupu Qpony.pl Sp. z o.o.

\begin{tabular}{|c|c|}
\hline Faza rozwoju organizacji & Model biznesowy - kluczowe aspekty \\
\hline Faza koncepcyjna - pre-seed (2010-2012) & $\begin{array}{l}\text { - kanał tradycyjny (papierowy katalog) } \\
\text { - segmenty klientów (lokalni przedsiębiorcy oraz restauracje sieciowe) } \\
\text { - walidacja propozycji wartości } \\
\text { - sposób finansowania - rodzina }\end{array}$ \\
\hline Faza zalążkowa - seed (2012-2014) & $\begin{array}{l}\text { - otwarcie kanału mobilnego (aplikacja mobilna) } \\
\text { - kluczowe zasoby (liczba użytkowników aplikacji mobilnej) } \\
\text { - segmenty klientów - klienci sieciowi, galerie handlowe } \\
\text { - strumienie przychodów - } 80 \% \text { z kanału tradycyjnego (papier) } \\
\text { - zysk ze sprzedaży: ujemny } \\
\text { - sposób finansowania - inwestycja seed - } 100 \text { tys. zł (AIP Seed Capital) }\end{array}$ \\
\hline Faza wczesnego wzrostu (2014-2016) & $\begin{array}{l}\text { - } \text { rozwój kanału mobile } \\
\text { - kluczowe zasoby (liczba użytkowników aplikacji mobilnej, pozycja rynkowa) } \\
\text { - strumienie przychodów - poszukiwanie źródeł przychodów z kanału mobile } \\
\text { - } \text { wykupienie udziałów dotychczasowych inwestorów } \\
\text { - zysk ze sprzedaży: ujemny } \\
\text { - } \text { sposób finansowania - inwestycja early stage funduszu Venture Capital w wysokości } 1 \mathrm{mln} \text { zł } \\
\text { (2014) oraz dodatkowa inwestycja związana z realizacją celów biznesowych w wysokości ponad } \\
1 \mathrm{mln} \text { zł }\end{array}$ \\
\hline Faza wzrostu i ekspansji (2016-...) & $\begin{array}{l}\text { - strumienie przychodów - rozwój przychodów z kanału mobile } \\
\text { - ekspansja na rynki zagraniczne - Ukraina } \\
\text { - przekroczenie progu rentowności w } 2017 \text { roku } \\
\text { - zysk ze sprzedaży: w } 2016 \text { ujemny wynoszący - 2,1 mln zł, w } 2017 \text { dodatni wynoszący } 0,9 \text { mln zł } \\
\text { - pierwsza akwizycja 2016, źródło finansowania - dług } \\
\text { - druga akwizycja 2018, źródło finansowania, kapitał własny }\end{array}$ \\
\hline
\end{tabular}

Źródło: opracowanie własne z uwzględnieniem modelu Canvas (Osterwalder, Pinguer, 2010)

Tabela 3. Zestawienie wybranych mierników rozwoju startupu - MAU oraz wskaźniki finansowe w latach 2012-2017

\begin{tabular}{|c|c|c|c|c|c|c|c|c|c|c|}
\hline & $2012^{*}$ & 2013 & 2014 & $\begin{array}{c}\text { zmiana } \\
\mathrm{r} / \mathrm{r}\end{array}$ & 2015 & $\begin{array}{l}\text { zmiana } \\
\mathrm{r} / \mathrm{r}\end{array}$ & $2016 * *$ & $\underset{r / r}{z m i a n a}$ & 2017 & $\underset{\mathrm{r} / \mathrm{r}}{\text { zmiana }}$ \\
\hline $\begin{array}{c}\text { Średnia miesięczna } \\
\text { liczba aktywnych } \\
\text { użytkowników aplikacji } \\
\text { (MAU w tys.) }\end{array}$ & 15 & 30 & 135 & $350 \%$ & 245 & $81 \%$ & $\begin{array}{c}300 / \text { po } \\
\text { akwizy- } \\
\text { cji } 650\end{array}$ & $165 \%$ & 1025 & $57 \%$ \\
\hline Przychody (tys. zł) & 74,6 & 253,4 & 1031,9 & $307 \%$ & 2256,8 & $118 \%$ & 3720,8 & $64 \%$ & 7561,1 & $103 \%$ \\
\hline Koszty (tys. zł) & 108,6 & 284,7 & 1505,8 & $428 \%$ & 3926,9 & $160 \%$ & 5823,4 & $48 \%$ & 6646,9 & $14 \%$ \\
\hline $\begin{array}{c}\text { Zysk/strata ze sprzedaży } \\
\text { (tys. zł) }\end{array}$ & -34 & $-31,3$ & $-473,9$ & & $-1670,1$ & & -2103 & & 914,2 & \\
\hline
\end{tabular}

* spółka istnieje od drugiej połowy 2012 roku

** w drugiej połowie 2016 akwizycja aplikacji konkurencyjnej w celu zwiększenia udziału w rynku 
pod uwagę jego zyskowności jako warunku funkcjonowania, a jedynie szeroko rozumiany potencjał do generowania dodatnich przepływów gotówkowych w przyszłości. Warunkiem tego jest jednak utrzymanie określonego tempa wzrostu, który rozumiany jest jako inwestycja w aktywa niematerialne. W tym może tkwić wyjaśnienie dynamicznego rozwoju tego typu organizacji w porównaniu z przedsiębiorstwami funkcjonującymi na tradycyjnych rynkach i wykorzystującymi wyłącznie fizyczne kanały dystrybucji.

Oprócz odmiennego podejścia - bardziej ekspansywnej strategii wzrostu przyjmowanej przez założycieli startupów internetowych, czynnikiem sprzyjającym większej dynamice rozwoju tego typu organizacji jest przede wszystkim możliwość szybszego testowania rozwiązań produktowych i, co za tym idzie, sprawniejsza modyfikacja przyjętego modelu biznesu. Dotyczy to przede wszystkim zmian docelowych segmentów klientów, szybszego i łatwiejszego dostępu do głównych aktywów tworzących wartość przedsiębiorstwa. Dodatkowo, jak można zaobserwować na przykładzie analizowanego przypadku, istotnym czynnikiem stanowiącym konsekwencję wyboru modelu biznesu jest zainteresowanie inwestorów zapewniających finansowanie wzrostu i rozwoju organizacji.

\section{Podsumowanie}

W porównaniu do wielu opisywanych w literaturze modeli cyklu życia organizacji, rozwój przedsiębiorstw bazujących na rozwiązaniach internetowych i mobilnych może charakteryzować się skróceniem niektórych etapów oraz przyspieszeniem osiągania niektórych faz cyklu życia z uwagi na możliwości szybszego testowania nowych propozycji dla klienta, a, co za tym idzie, większą elastyczność w działaniu oraz szybszą reakcję na pojawiające się nowe okazje rynkowe. W przypadku startupu Qpony.pl decyzja o reorientacji modelu biznesu w kierunku rozwiązań internetowych i mobilnych oraz wsparcie kapitałowe sprzyjały osiągnięciu szybszej dynamiki wzrostu i rozwoju tej organizacji. Zmiana modelu biznesowego łączyła się z odpowiednim wyczuciem zmian rynkowych związanych z popularyzacją smartfonów.

Wnioskując, należy zwrócić uwagę na związek pomiędzy etapami życia startupu a otoczeniem rynkowym. Startupy jako przedsiębiorstwa innowacyjne wyprzedzają popyt rynkowy na oferowane produkty, w związku z czym należy analizować zarówno fazę życia, jak i model biznesu z uwzględnieniem szans rynkowych. Czynniki wpływające na elastyczność cyklu życia startupów internetowych mogą bowiem przyczynić się, poprzez odpowiednie zarządzanie, do wykorzystania tych szans, a tym samym do sukcesu przedsiębiorstwa.

Biorąc pod uwagę ograniczenia badania, należy zauważyć, że koncentruje się ono na początkowych i środkowych etapach cyklu życia, nie odnosząc się do sposobu wyjścia czy też zakończenia cyklu życia startupów, co powinno być $\mathrm{w}$ przyszłości przedmiotem dalszych analiz.
Z punktu widzenia badawczego jest bowiem istotne, czy podmioty te, dynamicznie rozwijające się $\mathrm{w}$ początkowych etapach, są trwałym bytem $\mathrm{w}$ gospodarce, podnoszącym poziom jej innowacyjności, i czy w związku z tym po szybkim wzroście następuje długa faza dalszej ekspansji lub stabilizacji, czy też dynamika rozwoju tych podmiotów jest związana również ze skróceniem całego cyklu ich życia. W kontekśsie przetrwania ${ }^{1}$ tych podmiotów należałoby uwzględnić szereg zjawisk związanych np. z decyzjami o przejęciach, połączeniu czy sprzedaży startupu. Przedstawiony przykład, zdaniem autorów, może być wstępem do analizy porównawczej strategii rozwoju poszczególnych startupów.

\section{dr Hanna Nowak \\ Uniwersytet Ekonomiczny w Poznaniu \\ Instytut Ekonomii \\ ORCID: 0000-0002-4760-3840 \\ e-mail: hanna.nowak@ue.poznan.pl}

\section{dr Krzysztof Łuczak \\ Uniwersytet Ekonomiczny w Poznaniu \\ Wydział Zarządzania \\ ORCID: 0000-0002-4933-4728 \\ e-mail: krzysztof.luczak@ue.poznan.pl}

\section{Przypis}

1) Artykuł wykorzystuje w części koncepcje związane $z$ realizacją projektu sfinansowanego ze środków Narodowego Centrum Nauki przyznanych na podstawie decyzji numer DEC-2011/01/N/HS4/01427.

\section{Bibliografia}

[1] Adizes I.K. (2015), Zarzq̨dzanie cyklem życia organizacji, tom 1: Jak organizacje rozwijaja się, dojrzewaja i umierają, Wyd. MT Biznes, Warszawa.

[2] Amit R., Zott Ch. (2001), Value Creation in e-business, „Strategic Management Journal”, Vol. 22, No. 6/7, pp. 493-520.

[3] Basich Z. (2014), Micro-VC Funds Plant Seeds, but Which Will Survive? The Private Equity Analyst. Dow Jones and Company, http://www.ventureinvestmentassociates.com/ pdf/DJ_PEVC_Sept_25_2014.pdf, access date: 20.02.2017.

[4] Blank S., Dorf B. (2013), Podręcznik startupu. Budowa wielkiej firmy krok po kroku, Wyd. Helion, Gliwice.

[5] Brzóska J., Jelonek D. (2015), Koncepcja pomiaru wartości tworzonej przez aplikacje modeli biznesu. Podstawy teoretyczne i studium przypadku, „Przegląd Organizacji”, Nr 9, s. $48-55$.

[6] Carter B. (2017), Coupon Statistics: The Ultimate Collection, Access Development, http://blog.accessdevelopment. com/ultimate-collection-coupon-statistics, access date: 17.02.2017.

[7] Churchill N.C., Lewis V.L. (1983), The Five Stages of Small Business Growth, „Harvard Business Review”, Vol. 61, No. 3, pp. 30-50. 
[8] Damodaran A. (2009). Valuing Young, Start-up and Growth Companies: Estimation Issues and Valuation Challenges, pp. 3-16, http://people.stern.nyu.edu/adamodar/pdfiles/papers/younggrowth.pdf, access date: 17.02.2017.

[9] Dobiegała-Korona B. (2012), Nowa rola marketingu $w$ budowie wartości przedsiębiorstwa, „Kwartalnik Nauk o Przedsiębiorstwie”, Nr 2, http://przedsiebiorstwo.waw.pl/ files/52/669/knob-2-2012-dobiegala-korona.pdf, data dostępu: 15.02.2017 r.

[10] Doligalski T. (2014), Model biznesu z perspektywy ogólnej teorii systemów, [w:] T. Doligalski (red.), Modele biznesu $w$ Internecie. Teoria i studia przypadków polskich firm, Wyd. Naukowe PWN, Warszawa, s. 13-27.

[11] Dziennik Internautów (2016), http://di.com.pl/qponypl-kupily-blixa-powstala-druga-najwieksza-grupa-mobilna-w-polsce-55130, data dostępu: 20.02.2017 r.

[12] Falencikowski T. (2013), Spójność modeli biznesu. Koncepcja i pomiar, CeDeWu, Warszawa.

[13] Galica M. (2012), Smartfonizacja Polaków 2012, Raport: Marketing Mobilny w Polsce 2012-2013, s. 25-37, http://jestem. mobi/wpcontent/uploads/2013/01/Raport_marketing_mobilny_w_Polsce_2012_2013_jestemmobi.pdf, data dostepu: $1.02 .2013 \mathrm{r}$.

[14] Giełzak M., Krok M. (2016), Źródła finansowania startupów - część 1 - Wprowadzenie, http://www.pi.gov.pl/ PARP/chapter_86197.asp?soid=5F2B3EF5200148EE805396220545DB77, Portal Innowacji, data dostępu: 24.02.2017 r.

[15] Glinka B., Pasieczny J. (2015), Tworzenie przedsiębiorstwa. Szanse, realizacja, rozwój, Wyd. Uniwersytetu Warszawskiego, Warszawa.

[16] Google Play, https://play.google.com, data dostępu: 10.12.2018 $\mathrm{r}$

[17] Greiner L.E. (1998), Evolution and Revolution as Organizations Grow, „Harvard Business Review”, Vol. 76, No. 3, pp. 55-67.

[18] Inkubatory.pl (2015), https://inkubatory.pl/wp-content/ uploads/2015/07/Wyjscie-za-milion.-Fundusz-Seed-Capital-sprzedal-udzialy-w-znanym-startupie.docx, data dostępu: 20.02.2017 r.

[19] Kardas M. (2016), Pojęcia i typy modeli biznesu, [w:] K. Klincewicz (red.), Zarzadzanie, organizacje $i$ organizowanie. Przegląd perspektyw teoretycznych, Wyd. Naukowe Wydziału Zarządzania Uniwersytetu Warszawskiego, Warszawa, s. 298-318.

[20] Kopecka-Piech K. (2013), Aplikacje mobilne: innowacyjność, sytuacyjność $i$ personalizacja komunikacji marketingowej i wizerunkowej, „Nowe Media”, Nr 4, s. 11-30.

[21] Krajowy Rejestr Sądowy, https://ekrs.ms.gov.pl/, data dostępu: 10.12.2018 r.

[22] Kurowska M., Szymańska K., Walecka A. (2013), Wewnętrzne determinanty rozwoju przedsiębiorczości technologicznej w firmach sektora MSP, [w:] S. Lachiewicz, M. Matejun, A. Walecka (red.), Przedsiębiorczość technologiczna w matych $i$ średnich firmach. Czynniki rozwoju, Wyd. WNT, Warszawa, s. $25-48$.

[23] Mamstartup.pl (2016), http://mamstartup.pl/inwestycje/ 9002/qpony-przejmuja-blixa-aplikacje-stworzona-przez -19-latka, data dostępu: 20.02.2017 r.
[24] Matejun M. (2016), Statyka i dynamika w cyklu życia mikro-, matych $i$ średnich przedsiębiorstw, Prace Naukowe Uniwersytetu Ekonomicznego we Wrocławiu, Nr 419, s. 95-106.

[25] Matejun M. (2011), Faza startowa jako strategiczny etap rozwoju przedsiębiorstwa, [w:] S. Lachiewicz, M. Matejun (red.), Zarządzanie rozwojem małych $i$ średnich przedsiębiorstw, Oficyna Wolters Kluwer business, Warszawa, s. 61-84.

[26] Newsweek (2012), http://www.newsweek.pl/biznes/wiadomosci-biznesowe/konkurs-house-of-walkers-project--znamy-zwyciezcow-,92767,1,1.html, data dostępu: 20.02.2017 r.

[27] Nogalski B. (2009), Modele biznesu jako narzędzia reorientacji strategicznej przedsiębiorstw, „Master of Business Administration", Tom 17, Nr 2, s. 3-14.

[28] Osterwalder A., Pigneur Y. (2010), Tworzenie modeli biznesowych, Helion, Gliwice.

[29] Porter M.E. (2006), Harvard Business Review. Doskonalenie strategii, Helion, Gliwice.

[30] Ritchie R. (2017), History of iPhone, 10 Years Ago Today, Apple and iPhone Changed our World, http://www.imore. com/history-iphone-original, access date: 20.02.2017.

[31] Spinelli S., Adams R. (2012), New Venture Creation. Entrepreneurship for the 21st Century, McGraw-Hill, Irwin.

[32] Startup Poland (2016), Polskie Startupy. Raport 2016.

[33] Startup Poland (2017), Polskie Startupy. Raport 2017.

[34] Szpringer W. (2012), Innowacyjne modele e-biznesu. Aspekty instytucjonalne, Difin, Warszawa.

[35] Świeszczak K. (2016), Uwarunkowania skuteczności działania inkubatorów przedsiębiorczości, Wyd. Uniwersytetu Łódzkiego, Łódź.

[36] Tuttle B. (2010), The History of Coupons, http://business. time.com/2010/04/06/the-history-of-coupons/, access date: 20.02.2017.

[37] Waniak-Michalak H. (2015), Wsparcie matych i średnich przedsiębiorstw przez organizacje niedziałajace dla zysku. Znaczenie, Ewidencja. Raportowanie, Difin, Warszawa.

[38] Wasilczuk J. (2004), Fazy rozwoju przedsiębiorstwa - podejście modelowe. Uwagi wstępne, [w:] F. Bławat (red), Przetrwanie i rozwój małych i średnich przedsiębiorstw, Scientific Publishing Group, Gdańsk, s. 71-73.

\section{Business Models and the Lifecycle of Internet Start-ups. A Case Study}

\section{Summary}

Technological progress has created new conditions for the functioning of enterprises based on new business models. The paper examines the impact of choosing web-based or mobile business models on the organisation's lifecycle. The case of the start-up activity presented in the paper justifies the statement about the impact that choosing an internet-based business model has on the facilitation and acceleration of the organisation's growth and development.

\section{Keywords}

business lifecycle, business model, internet start-up 